\title{
PENURUNAN JUMLAH CACAT DAN BIAYA BAHAN BAKU DENGAN METODE RESPONSSE SURFACE
}

\author{
MUHAMMAD LUKMAN, AHMAD ZUBAID FIRDAUS, RAHADIAN GALIH \\ Jurusan Teknik Industri, Fakultas Teknik, Universitas Muhammadiyah Malang \\ Jl. Raya Tlogomas No. 246 Malang \\ Laman : lukmanumm@yahoo.com
}

\begin{abstract}
ABSTRAK
CV Indah Cemerlang adalah salah satu perusahaan yang bergerak dalam bidang industri bahan bangunan yaitu produk paving. Dalam proses produksi perusahaan sering melakukan perubahan komposisi bahan baku yang dipengaruhi oleh biaya bahan baku. Faktor perubahan komposisi bahan baku ini membuat kualitas mutu produk mengalami penurunan. Oleh karena itu perlu diadakan suatu penelitian untuk mengidentifikasi faktor-faktor kontrol yang berpengaruh terhadap respons cacat dengan metode Responsse Surface. Penelitian dengan metode Responsse Surface ini mempunyai dua tahap. Tahap pertama yaitu orde 1 (screening) dan tahap kedua yaitu orde 2 (optimization). Hasil orde 1 diketahui komposisi bahan baku yang memengaruhi respons cacat yaitu volume semen dan abu batu. Berdasarkan hasil tersebut maka pada tahap kedua yaitu orde 2 dilakukan percobaan untuk menentukan komposisi bahan baku yang optimal. Setting komposisi bahan baku terbaik yaitu air 20 liter, semen 47 kg, pasir 120 kg, abu batu 10,45 takaran, dengan nilai respons kecacatan sebesar 5,08 persen. Penurunan biaya bahan baku dengan menggunakan komposisi tersebut sebesar Rp49,33 per palet dan biaya kerugian kualitas mengalami penurunan sebesar Rp47.640 per minggu.
\end{abstract}

Kata kunci : metode responsse surface, cacat, optimasi

\begin{abstract}
CV. Indah Cemerlang is a company for building material which produces paving stone. The company often changes the raw materials composition which is affected by cost of raw materials. Change of the raw materials composition makes product quality lower. Therefore, a study should be conducted in order to identify control factors influencing on defect responsse by using Responsse Surface method. Responsse surface method used in this research consists of two stages. First stage, called orde 1, is dealing with screening and second stage, called orde 2, is dealing with optimization. The result of orde 1 shows that the raw materials composition influencing on defect responsse are cement volume and gray stone. According to the result of second stage, the experiment is conducted to determine optimal amount of raw materials composition. Optimal amount of the raw materials composition are 20 liters of water, 47 kilograms of cement, 120 kilograms of sand, and 10.45 doses of gray stone, with value of defect responsse 5.08\%. Applying proposed composition can decrease cost of raw material by Rp 49,33 per pallet and cost of poor quality by 47.60 per week.
\end{abstract}

Key words: responsse surface method, defect, optimization

\section{PENDAHULUAN}

Industri bahan bangunan pada saat sekarang ini sedang mengalami persaingan yang cukup berat, khususnya pada industri bahan bangunan paving. Hal ini dikarenakan berkembangnya pembangunan sarana perumahan, pertokoan, dan sarana pembangunan lainnya. Demikian halnya yang dialami CV Indah Cemerlang sebagai salah satu perusahaan yang bergerak dalam bidang industri bahan bangunan dengan sifat produksi secara kontinyu. Jenis-jenis produk yang dihasilkannya oleh perusahaan ini adalah paving diagonal, paving straight, paving trihexagonal, paving grass block (rumput). Kapasitas yang 
dihasilkan setiap hari sebanyak 8400 unit. Perusahaan telah menetapkan karakteristik mutu paving yang diproduksi, yaitu karakteristik mutu K-200 berdasarkan SII.08.1983 (uji beton lantai).

Dalam proses pembuatan dan hasil akhir berupa produk tidak terlepas dari cacat. Salah satu cacat yang terjadi di perusahaan ini disebut sebagai cacat fisik. Produk yang dikategorikan cacat fisik meliputi hancur, hancur sebagian dan hancur dibagian permukaan atas. Produk cacat fisik yang dihasilkan dalam satu hari produksi dapat mencapai rata-rata 380 unit. Produk cacat fisik disebabkan perubahan komposisi material yang digunakan. Jika hal ini terus berlangsung pada proses produksi maka akan mengakibatkan kerugian bagi perusahaan. Penelitian ini bertujuan untuk mengidentifikasi faktor-faktor kontrol yang berpengaruh terhadap performansi produk serta mendapatkan komposisi terbaik dalam menghasilkan produk yang bebas cacat dan biaya bahan baku yang minimum.

Salah satu metode dalam desain eksperimen adalah Response Surface Method (RSM). Metode ini menggabungkan teknik matematika dengan teknik statistika yang digunakan untuk membuat dan menganalisa suatu respons $\mathrm{Y}$ yang dipengaruhi oleh beberapa variabel bebas atau faktor X guna mengoptimalkan respons tersebut (Rahardjo, 2002). Metode response surface seringkali digunakan pada bidang industri untuk meminimalisasi kecacatan suatu produk, selain itu metode response surface juga bisa digunakan untuk bidang yang lain seperti bidang ilmu pangan, biologi, ilmu kedokteran dan kesehatan (Myers et al., 2009). Penggunaan metode response surface diharapkan dapat meminimalkan penyimpangan-penyimpangan yang terjadi, yaitu mengurangi jumlah cacat produk dan biaya produksi serta memberikan masukan kepada perusahaan sehingga dihasilkan produk yang optimal.

\section{METODE}

Metode response surface adalah teknik yang digunakan untuk memodelkan antara variabel responss dan faktor perlakuan. Metode responsse surface menghasilkan solusi optimum yang dapat dipilih untuk kondisi maksimum, minimum dan kondisi hasil yang diinginkan sepanjang batas atas dan sepanjang batas bawah (Bachtiar dan Amrillah, 2011). Secara umum, metode responsse surface dapat digambarkan secara visual melalui responsse surface plot dan kontur plot. Melalui plot tersebut dapat diketahui bentuk hubungan antara responss dengan variabel bebasnya (Supartini, 2012). Metode responsse surface merupakan salah satu metode yang dapat digunakan untuk melakukan proses optimasi responss pada percobaan dengan faktor perlakuan bersifat kuantitatif. Aplikasi metode responsse surface banyak dilakukan pada beberapa bidang. Penelitian oleh Demirel dan Kayan (2012), Fnides et al. (2011), Tan et al. (2012) menggunakan metode response surface untuk mendapatkan komposisi taraf perlakuan yang menghasilkan respons optimum.

Proses penerapan RSM dimulai dari identifikasi karakteristik produk. Identifikasi karakteristik produk dimulai dengan mengidentifikasi faktor-faktor apa saja yang memengaruhi terhadap respons. Respons yang diamati yakni jumlah cacat, di mana variabel respons (y) adalah jumlah. Sedangkan variabel kontrol adalah bahan baku air $\left(\mathrm{X}_{1}\right)$ dengan satuan liter, semen $\left(\mathrm{X}_{2}\right)$ dengan satuan kilogram, pasir $\left(\mathrm{X}_{3}\right)$ dengan satuan kilogram dan abu batu $\left(\mathrm{X}_{4}\right)$ dengan satuan takaran (ember). Variabel kontrol yang diamati digunakan dalam membuat satu kali adonan produk paving. Penelitian ini menggunakan metode response surface orde 1 dan orde 2.

RSM Orde 1 memiliki beberapa tahapan yang dilakukan dimulai dengan penentuan variabel dan level. Pada tahap ini ditentukan variabel-variabel bebas, di mana variabel ini diasumsikan merupakan variabel kontinyu dan dapat dikendalikan oleh peneliti ( $k$ kode $\mathrm{X}_{1}, \mathrm{X}_{2}, .$. , $\mathrm{Xn}$ ) dari hasil suatu proses serta menentukan nilai level ditiap-tiap faktor (variabel bebas) yang digunakan untuk mengoptimalkan suatu variabel respons/tak bebas diasumsikan merupakan 
variabel acak (dengan kode Y). Berikut kode dan ekperimen orde 1 seperti yang terlihat pada tabel 1.

Tabel 1. Kode dan eksperimen orde 1

\begin{tabular}{ccc}
\hline Kode & $\mathbf{- 1}$ & $\mathbf{+ 1}$ \\
\hline $\mathrm{X}_{1}$ & & \\
$\mathrm{X}_{2}$ & & \\
$\mathrm{X}_{\mathrm{n}}$ & & \\
\hline
\end{tabular}

Di mana, $\mathrm{X}_{1}, \mathrm{X}_{2}, \ldots, \mathrm{X}_{\mathrm{n}}$ : identitas suatu kode faktor (jenis-jenis bahan baku)

$+1,-1$ : batas atas dan bawah dari suatu nilai level

Setelah didapatkan kode maka tahap selanjutnya menghitung efek-efek faktor. Rancangan permukaan respons dengan faktorial $2^{\mathrm{k}}$ digunakan untuk menghitung efek faktor pada orde pertama. Rancangan faktorial $2^{\mathrm{k}}$ dipergunakan untuk percobaan yang terdiri dari $\mathrm{k}$ faktor (disebut sebagai variabel bebas), di mana setiap variabel diberi kode yang bersifat baku yaitu -1 dan +1 . Model dasar orde 1 adalah sebagai berikut (Gaspersz, 1995).

$y=\beta_{0}+\sum_{i=1}^{k} \beta_{1} x_{1}+\varepsilon$ 1

di mana: $\mathrm{Y}=$ variabel respons yang diamati

$\beta=$ nilai parameter

$\mathrm{X}_{\mathrm{i}}$ = variabel bebas/faktor $(\mathrm{i}=1,2,3, \ldots, \mathrm{k})$

$\varepsilon \quad=$ error

Rancangan eksperimen pada orde pertama akan dilakukan pengujian statistik dengan ANOVA. Tahap selanjutnya adalah menganalisa residual, pemeriksaan asumsi residual (asumsi normalitas, homogenitas varians, independen) yang meliputi uji independen, uji identik, dan uji kenormalan dilakukan dengan membuat plot menggunakan software Minitab. Jika ketiga asumsi tersebut telah terpenuhi maka model dinyatakan valid (Montgomery, 2009). Tahap akhir dari metode orde 1 adalah menganalisis dan menyimpulkan faktor-faktor yang signifikan, selanjutnya faktor-faktor yang signifikan akan digunakan untuk rancangan eksperimen orde 2. Perbaikan model dilakukan setelah diketahui faktor-faktor yang signifikan, karena model baru hanya berisi faktor-faktor yang berpengaruh.

Metode RSM Orde 2 didasarkan hasil dari orde 1 . Rancangan eksperimen orde 2 didasarkan pada faktor-faktor yang terpilih sebelumnya kemudian akan diteliti dengan rancangan faktorial $3^{\mathrm{k}}$ yaitu suatu percobaan faktorial yang masing-masing faktor terdiri dari tiga taraf dengan kode $-1,0$, dan +1 . Model dasar orde 2 adalah sebagai berikut (Gaspersz, 1995):

$$
\begin{aligned}
& \mathrm{y}=\beta_{0}+\sum_{i=1}^{k} \beta_{\mathrm{i}} \mathrm{x}_{\mathrm{i}}+\sum_{i=1}^{k} \beta_{\mathrm{ii}} \mathrm{x}_{\mathrm{i}}^{2}+\cdots+\sum_{\mathrm{i}<j} \sum \beta_{\mathrm{ii}}
\end{aligned}
$$

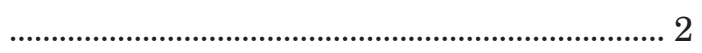

$$
\begin{aligned}
& \text { di mana: } \mathrm{Y} \quad=\text { variabel respons yang } \\
& \text { diamati } \\
& \beta=\text { nilai parameter } \\
& \mathrm{X}_{\mathrm{ij}} \quad=\text { variabel bebas/faktor } \\
& (\mathrm{ij}=1,2,3, \ldots, \mathrm{k}) \\
& \mathrm{X}_{\mathrm{i}}{ }^{2} \quad \text { = variabel bebas/faktor } \\
& (\mathrm{i}=1,2,3, \ldots, \mathrm{k}) \text { dikuadratkan } \\
& \varepsilon \quad=\text { error }
\end{aligned}
$$

Pengujian residual pada desain faktorial $3^{\mathrm{k}}$ adalah sama dengan pengujian pada faktorial $2^{\mathrm{k}}$. Di mana jika analisa residual dari faktorfaktor sudah terpenuhi, maka pengujian ANOVA dinyatakan valid dan dapat dilakukan dengan analisa selanjutnya. Seperti pada orde 1, hasil perhitungan faktorial pada eksperimen orde kedua dilakukan pengujian statistik ANOVA. Proses perbaikan model dilakukan setelah diketahui faktor-faktor yang signifikan melalui uji statistik, sehingga diketahui model yang berisi faktor-faktor yang berpengaruh. Tahap selanjutnya adalah menentukan model optimasi. Model ini merupakan hasil akhir yang diperoleh dari rumus rancangan eksperimen orde 2 setelah dilakukan pengujian statistik. Setelah model optimasi ditentukan, langkah selanjutnya adalah menentukan kondisi optimum dari faktor-faktor yang signifikan. Proses ini dapat dijelaskan dengan sebuah grafik Contour Plot of Response, sehingga karakter permukaan respons dapat 
diketahui. Hasil dari faktor-faktor optimum akan dilakukan perhitungan biaya untuk mendapatkan biaya bahan baku yang minimum dan biaya kerugian kualitas.

\section{HASIL DAN PEMBAHASAN}

\section{Eksperimen Orde 1}

Orde 1 adalah rancangan faktorial dengan rumus $2^{\mathrm{k}}$ yang digunakan untuk eksperimen yang terdiri dari $\mathrm{k}$ faktor yang masing-masing variabel diberi kode yang bersifat baku yaitu -1 dan -1. Dalam penelitian ini orde 1 merupakan tahap penyaringan faktor (screening) dengan desain faktorial dua level dan empat faktor. Dengan menggunakan persaman 1 dilakukan uji asumsi dasar dengan menggunakan uji normalitas, uji homogenitas, dan uji independen. Apabila seluruh data yang dihasilkan tersebut telah terpenuhi maka model dinyatakan valid. Pengujian signifikansi menggunakan analisis variansi (ANOVA) dilakukan terhadap respons jumlah kecacatan untuk mengetahui apakah faktor-faktor yang diteliti berpengaruh signifikan terhadap variabel respons tersebut. Hasil perhitungan uji signifikasi untuk orde 1 dengan ANOVA ditunjukkan pada Tabel 2.

Sumber variansi untuk regresi dan interaksi diperoleh keputusan diterima sedangkan keputusan pada sumber variansi untuk linier adalah ditolak. Kesimpulan yang diperoleh dari uji signifikasi adalah efek-efek faktor air, semen, pasir, dan abu batu berpengaruh secara signifikan terhadap respons kecacatan secara linier sedangkan secara interaksi tidak berpengaruh secara signifikan. Langkah selanjutnya adalah melakukan perhitungan $\mathrm{p}$ value dengan menggunakan tingkat keyakinan $\alpha=5 \%$ dengan software Minitab, hasilnya dapat dilihat pada tabel 3 .

Dari hasil perhitungan untuk eksperimen orde 1 ini disimpulkan bahwa faktor-faktor yang signifikan adalah terhadap respons cacat adalah

Tabel 2. Hasil Perhitungan Uji ANOVA untuk Orde 1

\begin{tabular}{lrrrrrc}
\hline \multicolumn{1}{c}{ Sumber Variansi } & \multicolumn{1}{c}{ Dk } & \multicolumn{1}{c}{ JK } & MS & $\mathbf{F}_{\text {hitung }}$ & $\mathbf{F}_{\text {tabel }}$ & Keputusan \\
\hline Regresi & 10 & 13,9313 & 1,39313 & 3,9446 & 4,74 & Diterima \\
- Linier & 4 & 12,1575 & 3,03938 & 8,73818 & 5,19 & Ditolak \\
- Interaksi & 6 & 1,7738 & 0,29563 & 0,74895 & 4,95 & Diterima \\
Residual Error & 5 & 3,6931 & 0,73863 & & & \\
Total & 15 & 17,6244 & & & & \\
\hline
\end{tabular}

Tabel 3. Hasil Uji P Value untuk Orde 1 dengan Software Minitab

\begin{tabular}{|c|c|c|c|c|}
\hline Term & Coef & SE Coef & $\mathbf{T}$ & $\mathbf{P}$ \\
\hline Constant & 5,5188 & 0,1608 & 34,324 & 0,000 \\
\hline air & 0,3187 & 0,1608 & 1,982 & 0,104 \\
\hline semen & $-0,6813$ & 0,1608 & $-4,237$ & 0,008 \\
\hline pasir & 0,0063 & 0,1608 & 0,039 & 0,970 \\
\hline abu batu & $-0,5813$ & 0,1608 & $-3,615$ & 0,015 \\
\hline air*semen & 0,0937 & 0,1608 & 0,583 & 0,585 \\
\hline air*pasir & $-0,0187$ & 0,1608 & $-0,117$ & 0,912 \\
\hline air*abu batu & $-0,0813$ & 0,1608 & $-0,505$ & 0,635 \\
\hline semen*pasir & 0,0062 & 0,1608 & 0,039 & 0,970 \\
\hline
\end{tabular}


semen $\left(\mathrm{X}_{2}\right)$ dan abu batu $\left(\mathrm{X}_{4}\right)$ dengan rumusan model sebagai berikut :

$$
\mathrm{Y}=5,5188-0,6813 \mathrm{X}_{2}-0,5813 \mathrm{X}_{4}+\varepsilon
$$

\section{Eksperimen Orde 2}

Berdasarkan hasil eksperimen orde 1 telah diketahui faktor yang signifikan yaitu semen dan abu batu. Kedua faktor tersebut akan diteliti dengan menggunakan rancangan 3 level di mana 3 level tersebut dikodekan dengan $(-1,0,1)$ pada rancangan orde 2 (tahap optimasi). Rumus rancangan model orde 2 dapat dilihat pada persamaan 2. Berdasarkan hasil perhitungan untuk orde 1 , faktor air dan pasir tidak signifikan terhadap respons cacat, maka level dari kedua faktor tersebut akan dipilih nilai level yang paling kecil yaitu 20 liter untuk air dan 120 kilogram untuk pasir. Hal ini dikarenakan biaya kebutuhan bahan baku untuk level yang minimum lebih murah.

Pada rancangan orde 2 dilakukan uji asumsi dasar. Hasil perhitungan uji normalitas, uji homogenitas, uji independen seluruh data dinyatakan valid. Langkah selanjutnya dilakukan uji signifikansi dengan ANOVA untuk mengetahui faktor-faktor yang berpengaruh terhadap respons cacat. Dari hasil perhitungan uji ANOVA hasil orde 2 dapat dilihat pada Tabel 4 .

Keseluruhan keputusan pada sumber variansi untuk regresi, linier, dan interaksi adalah diterima. Kesimpulan yang diperoleh dari uji signifikasi adalah semua efek-efek faktor semen, abu batu dan setiap interaksi tidak berpengaruh secara signifikan terhadap respons kecacatan. Sedangkan hasil pengujian $\mathrm{p}$ value dengan tingkat keyakinan $\alpha=5 \% \mu \varepsilon v \gamma \gamma v v \alpha \kappa \alpha v$ software Minitab adalah sebagai berikut :

Hasil perhitungan $\mathrm{p}$ value dengan menggunakan software Minitab didapatkan bahwa seluruh kondisi variabel (tiap-tiap faktor dan interaksi) tidak berpengaruh secara signifikan terhadap respons cacat di mana seluruh nilai $\mathrm{p}$ value pada tabel diatas menunjukkan bahwa nilai tersebut lebih besar dari $\alpha=0,05$. Syarat-syarat dari perhitungan uji statistik terpenuhi, maka diketahui hasil dari orde 2 di

Tabel 5. Hasil Uji p value untuk Orde 2 dengan Software Minitab

\begin{tabular}{lcccc}
\hline \multicolumn{1}{r}{ Term } & Coef & SE Coef & T & P \\
\hline Constant & 4,3000 & 0,3135 & 13,715 & 0,001 \\
semen & $-0,4500$ & 0,1717 & $-2,620$ & 0,079 \\
abu batu & 0,1833 & 0,1717 & 1,068 & 0,364 \\
semen* & 0,6500 & 0,2974 & 2,185 & 0,117 \\
semen & & & & \\
abu & 0,6500 & 0,2974 & 2,185 & 0,117 \\
batu*abu & & & & \\
batu & & & & \\
semen*abu batu $-0,1750$ & $0,2103-0,8320,466$ &
\end{tabular}

Tabel 4. Hasil Perhitungan Uji ANOVA untuk Orde 2

\begin{tabular}{lcrrrrc}
\hline Sumber Variansi & Dk & \multicolumn{1}{c}{ JK } & \multicolumn{1}{c}{ MS } & $\mathbf{F}_{\text {hitung }}$ & $\mathbf{F}_{\text {tabel }}$ & Keputusan \\
\hline Regresi & 3 & 1,53917 & 0,513056 & 1,16 & 5,41 & Diterima \\
- Linier & 2 & 1,41667 & 0,70833 & 1,5947 & 5,79 & Diterima \\
- Interaksi & 1 & 0,1225 & 0,1225 & 0,2758 & 6,61 & Diterima \\
Residual Error & 5 & 2,22083 & 0,444167 & & & \\
Total & 8 & 3,76 & & & & \\
\hline
\end{tabular}




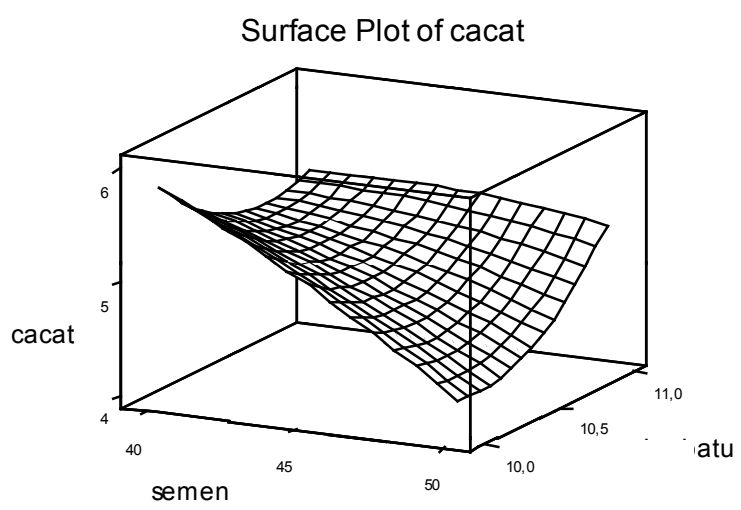

Gambar 1. Plot permukaan cacat terhadap semen dan abu batu

mana seluruh faktor dan interaksi menunjukkan tidak adanya signifikan. Model di orde 2 dapat dirumuskan sebagai berikut :

$\mathrm{Y}=5,1667-0,450 \mathrm{X}_{2}+0,1833 \mathrm{X}_{4}+0,650 \mathrm{X}_{2}^{2}+$ $0,650 \mathrm{X}_{4} 2-0,1750 \mathrm{X}_{2} \mathrm{X}_{4}+\varepsilon$

Setelah model optimasi ditentukan, langkah selanjutnya adalah menghitung titik stasioner. Perhitungan ini menggunakan matrik berdasarkan nilai koefisien hasil persamaan model pada orde 2, hasil perhitungan titik stasioner yaitu $\mathrm{X}_{2.0}$ (semen) $=0,33321$ dan $\mathrm{X}_{4.0}$ (abu batu) $=-0,091$. Titik ini disubsitusikan kedalam nilai variabel asli sehingga diperoleh komposisi untuk semen $47 \mathrm{~kg}$ dan abu batu 10,45 takaran dengan nilai respons kecacatan sebesar 5,08\%. Hasil plot permukaan cacat terhadap semen dan abu batu ditunjukkan pada Gambar 1.

Berdasarkan hasil perhitungan titik stasioner maka diketahui hasil dari variabel asli di tiaptiap faktor yang terpilih, selanjutnya menentukan biaya bahan baku ditiap-tiap sampel eksperimen. Berikut ini adalah harga bahan baku air $\mathrm{Rp}$ 25,- per liter, semen Rp 1250,- per kg, Pasir Rp 75.000 ,- per $\mathrm{m}^{3}$ dan abu batu Rp 80.000,- per $\mathrm{m}^{3}$. Hasil komposisi terpilih diketahui $\left(\mathrm{X}_{2}\right)=47 \mathrm{~kg}$ $\left(0,312 \mathrm{~m}^{3}\right)$ dan abu batu $\left(\mathrm{X}_{4}\right)=10,45$ takaran $\left(0,407 \mathrm{~m}^{3}\right)$, sedangkan untuk air dan pasir dipilih nilai level yang paling kecil yaitu $\mathrm{X}_{1}=20$ liter dan $\mathrm{X}_{2}=8$ takaran untuk pasir. Hal ini dikarenakan biaya bahan baku untuk level yang minimum lebih murah. Biaya bahan baku pada kondisi
Tabel 6. Perbandingan Hasil Perhitungan Biaya pada Kondisi Awal dan Perbaikan

\begin{tabular}{lccc}
\hline \multicolumn{1}{c}{$\begin{array}{c}\text { Jenis } \\
\text { Biaya }\end{array}$} & $\begin{array}{c}\text { Kondisi } \\
\text { Awal }\end{array}$ & $\begin{array}{c}\text { Kondisi } \\
\text { Perbaikan }\end{array}$ & Satuan \\
\hline $\begin{array}{l}\text { Biaya } \\
\text { bahan baku }\end{array}$ & Rp 4.188,08 & Rp 4.138,75 & Palet \\
$\begin{array}{l}\text { Biaya } \\
\text { kerugian } \\
\text { kualitas }\end{array}$ & Rp 623.863 & Rp 576.223 & Minggu \\
\hline
\end{tabular}

awal diperoleh hasil sebesar Rp 4.188,08 per palet sedangkan hasil perhitungan biaya bahan baku setelah perbaikan diperoleh hasil Rp 4.138,75 per palet, maka selisih biaya bahan baku pada kondisi awal dengan perbaikan sebesar Rp 49,33 per palet.

Harga jual produk paving yang tidak cacat sebesar Rp 348/unit dan produk cacat dijual seharga $\mathrm{Rp}$ 90/ unit. Biaya kerugian kualitas kondisi awal $\left(\mathrm{TC}_{\mathrm{A}}\right.$ ) dihitung dengan rumus (\% produk cacat awal $\mathrm{x}$ rata-rata produksi) $\mathrm{x}$ (harga jual produk kondisi baik-harga jual produk cacat $)=(5,5 \% \times 43.965) \times(\operatorname{Rp} 348-\operatorname{Rp} 90)=$ 623.863/minggu. Setelah dilakukan perbaikan dengan usulan komposisi bahan baku yang baru maka persentase cacat menurun menjadi 5,08\% sehingga biaya kerugian kualitas perbaikan $\left(\mathrm{TC}_{\mathrm{P}}\right)$ dihitung dengan rumus (\% cacat setelah perbaikan $\mathrm{x}$ rata-rata produksi) $\mathrm{x}$ (harga jual produk kondisi baik-harga jual produk cacat $)=$ $(5,08 \%$ x 43.965) $\times(\operatorname{Rp} 348-R p 90)=\operatorname{Rp} 576.223 /$ minggu. Selisih biaya kerugian kualitas pada kondisi awal dengan perbaikan sebesar Rp 47.640 per minggu. Perbandingan biaya bahan baku dan biaya kerugian kualitas pada kondisi awal dan perbaikan dapat dilihat pada Tabel 6 berikut.

\section{SIMPULAN}

Hasil metode response surface didapatkan komposisi terbaik berdasarkan cacat dan biaya bahan baku minimum yaitu air 20 liter, semen 47 kilogram, pasir $120 \mathrm{~kg}$, abu batu 10,45 takaran dengan persentase nilai cacat sebesar $5,08 \%$. Sedangkan biaya bahan baku mengalami penurunan dengan selisih sebesar Rp 49,33 per 
palet. Penentuan komposisi bahan baku terpilih ini tidak secara langsung dapat menurunkan jumlah cacat melainkan harus dilakukan pengujian untuk mendapatkan komposisi yang akurat. Selain itu perusahaan sebaiknya menstandarkan kualitas bahan baku untuk menghasilkan produk dengan persentase cacat yang seminimal mungkin.

\section{DAFTAR PUSTAKA}

Bachtiar, C. dan Amrillah R., 2011. Setting Parameter Mesin Press dengan Menggunakan Metode Respons Permukaan Pada Pabrik Kelapa Sawit, Jurnal Riset Industri, 5 (2), 153-160.

Demirel, M and Kayan, B. 2012. Application Of Response Surface Methodology and Central Composite Design for The Optimization of Textiledye Degradation by Wet Air Oxidation, International Journal of Industrial Chemistry, 3 (24).

Fnides, B. Yallese, M.A., Mabrouki, T., and Rigal, J.F., 2011. Aplication of Responsse Surface Methodology for Determining Cutting Force Model in Turning Hardened AISI H11 Hot Work Tool Steel, Sadhana, 36 (1), 109-123.
Gaspersz, V. 1995. Teknik Analisa dalam Penelitian Percobaan 2, Bandung: penerbit Tarsito.

Montgomery, D.C., 2009. Design and Analysis of Experiments. Ed ke-7. New York, John Wiley \& Sons, inc.

Myers, R.H, Montgomery, D.C., Anderson, M.C., 2009. Responsse Surface Methodology Process and Product Optimazation using Design Experiments, Third edition, New York, John Wiley and Sons, Inc.

Tan, Q.L.P., Thi Kieu, X.N., Thi Kim, N.H. and Thi Hong, X.N., 2012. Application of Responsse Surface Methodology (RSM) in Condition Optimization for Essential Oil Production from Citrus Latifolia, Emir. J. Food Agric, 24 (1), $25-30$.

Rahardjo, J. 2002. Optimasi Produksi Dengan Metode Responsse Surface. Jurnal Teknik Industri, 4 (1) $36-44$.

Supartini, E. dan Winarni, S., 2012. Kajian Terhadap Metode Responsse Surface Pada Desain Blok, Prosiding Seminar Nasional UNY. 